\title{
Correlation of Dysplastic Changes of Squamous Epithelial Cells to Bacterial Vaginosis Based on Nugent Score in the Cervical Smears of Patients with Vaginal Discharge
}

\author{
Packirisamy Aruna ${ }^{1}$, Kashish Arora ${ }^{2}$ \\ ${ }^{1}$ Assistant Professor, Department of Pathology, JIPMER KARAIKAL Thirunallar Byepass road, Kovilpathu, Karaikal, Puducherry UT- 602609, ${ }^{2}$ Final MBBS, \\ JIPMER, Dhanwantri Nagar, Puducherry.
}

\section{Abstract}

Background: Worldwide Cervical cancer is responsible for more than half a million new cases and a quarter of a million deaths annually. Many Researches has established the causal role of oncogenic human Papillomavirus (HPV) infection in the pathogenesis of invasive cervical cancer and its precursor lesions. Bacterial vaginosis (BV) is one of the most common conditions of childbearing aged women worldwide, and considering a possible synergy of an imbalanced vaginal environment with cervical preneoplasia, it is clear that greater attention needs to be given to this condition. Objective: To find out an association between Nugent score and dysplastic epithelial cell changes in the cervical smears of patients with vaginal discharge. Subjects and Methods: This is a descriptive study conducted on 100 cervical smears from women of reproductive group with vaginal discharge. Paponicolaou stained and Gram stained smears were studied. The proportion of cervical smears with normal flora and dysplastic changes as well as that of smears with Bacterial vaginosis and dysplastic changes were calculated and compared. Results: 19 smears were scored as BV,.2 out of 19 smears (10.5\%)were showing epithelial cell abnormality. 1 out of 38 (2.6\%)smears having normal vaginal flora was reported as ASC and 6 out of 43(14\%) smears in the intermediate category were reported as ASC(5) and HSIL (1). Statistical analysis was done by Chi-square test using IBM-SPSS Statistics-22 statistical package. The correlation between Bacterial vaginosis and dysplastic changes were not found to be statistically significant. Conclusion: There is no definite correlation of Bacterial vaginosis with dysplastic changes in the cervical smear of patients with vaginal discharge related with the risk for cervical carcinogenesis. Evaluation of larger cohort of subjects over a prolonged time frame is required to assess the influence of Bacterial vaginosis in cervical carcinogenesis.

Keywords: Bacterial Vaginosis, Nugent score, Cervical carcinogenesis.

Corresponding Author: Dr. Packirisamy Aruna, Assistant Professor of Pathology, JIPMER Karaikal Thirunallar Byepass road, Kovilpathu, Karaikal, Puducherry UT- 602609.

Email: arunameha@yahoo.co.in

Received: February 2020

Accepted: February 2020

\section{Introduction}

Bacterial vaginosis is defined as replacement of the lactobacilli of the vagina by characteristic groups of bacteria accompanied by changed properties of the vaginal fluid. It is a poly microbial condition and the microorganisms most often found are; Gardnerella vaginalis, Prevotella species, anaerobic gram positive cocci, Mycoplasma hominis and Mobiluncus species. ${ }^{[1]}$

Bacterial vaginosis (BV), one of the commonest vaginal disorders in females of re-productive age is associated with a number of obstetric and gynaecologic complications. The prevalence of BV has varied in studies from 10 to $64 \%$, depending on the method of detection used. The gold standard of diagnosis of BV is Nugent's scoring of gramstained smears. ${ }^{[2]}$

Cervical cancer, the second most common malignancy after breast cancer among women worldwide, is responsible for more than half a million new cases and a quarter of a million deaths annually. ${ }^{[3]}$

Many Researches has established the causal role of oncogenic humanpapilloma virus (HPV) infection in the pathogenesis of invasive cervical cancer and its precursor lesions, i.e. cervical intraepithelial neoplasia (CIN). However, HPV infection is widely prevalent among sexually active women and mostly self-limiting, causing only mild and transient cytological abnormalities. Just a small proportion of HPV-infected women will eventually develop cervical cancer, suggesting involvement of additional host or external factors acting together with HPV in cervical carcinogenesis. ${ }^{[4]}$

$\mathrm{BV}$ is one of the most common conditions of childbearing aged women worldwide, and considering a possible synergy of an imbalanced vaginal environment with cervical preneoplasia, it is clear that greater attention needs to be given to this condition. Previous studies examining the relationship between $\mathrm{BV}$ and CIN, however, have rendered 
conflicting results. The role of $\mathrm{BV}$ as a co-factor in the natural history of HPV infection and related disease remains largely elusive. The present study was aimed at evaluating the association, if any, of bacterial vaginosis in cervical smear and detection of pre-neoplastic lesion in the same smear. If BV plays a promoting role in the development of cervical cancer, then women with a history of recurrent or persistent BV should be liable for closer follow-up, and restoring the vaginal microflora should in that case be a promising answer.

\section{Review of Literature}

Grading the microbial flora seen in Gram stained vaginal smears for diagnosing BV was first described by Spiegel et al, but was found to be only moderately reliable because of the wide variability in recognizing bacterial morphotypes by Gram smear evaluators. ${ }^{[5]}$

Nugent et al by modifying this method to a semiquantitative scoring system provided a more standardized method of Gram stain interpretation for BV.

- Nugent scoring system classifies vaginal smears into normal flora, intermediate flora or BV infection according to the number of bacterial morphologies counted per field of vision. In this scale, a score of 0 to 10 is generated.

- The Nugent score will be calculated using the gram stained smears and would be interpreted using the given table.

\begin{tabular}{|l|l|l|}
\hline Organism morphotype & $\begin{array}{l}\text { Number/oil } \\
\text { immersion field }\end{array}$ & Score \\
\hline \multirow{4}{*}{$\begin{array}{l}\text { Lactobacillus-like } \\
\text { parallel sided, gram positive } \\
\text { rods) }\end{array}$} & $>30$ & 0 \\
\cline { 2 - 3 } & $5-30$ & 1 \\
\cline { 2 - 3 } & $1-4$ & 2 \\
\cline { 2 - 3 } & $<1$ & 3 \\
\cline { 2 - 3 } & 0 & 4 \\
\hline \multirow{4}{*}{$\begin{array}{l}\text { Mobiluncus-like } \\
\text { curved gram negative rods) }\end{array}$} & $>5$ & 2 \\
\cline { 2 - 3 } & $<1-4$ & 1 \\
\cline { 2 - 3 } & 0 & 0 \\
\hline \multirow{2}{*}{$\begin{array}{l}\text { Gardnerella/Bacteroides- } \\
\text { like(tiny, gram variable } \\
\text { coccobacilli and pleomorphic } \\
\text { rods with vacuoles) }\end{array}$} & $>30$ & 3 \\
\cline { 2 - 3 } & $5-30$ & 2 \\
\cline { 2 - 3 } & $1-4$ & 1 \\
\cline { 2 - 3 } & $<1$ & 0 \\
\cline { 2 - 3 } & 0 & \\
\hline
\end{tabular}

- Nugent results would be graded as 0-3 (normal vaginal state), 4-6 (intermediate grade bacterial colonization), and 7-10 (bacterial vaginosis). ${ }^{[6]}$

- Cervical cancer and pre-cancerous lesion have been causatively linked to persistent infection by human papillomavirus. ${ }^{[4]}$ However, numerous factors, including other sexually transmitted diseases, have been postulated to influence the progression from infection to high grade lesion. In this context, BV has also been implicated to play a role in cervical carcinogenesis. ${ }^{[7]}$

- Many authors have supported this association of BV with cervical pre-cancerous lesions. Biochemical changes in vaginal secretions of women with $\mathrm{BV}$ include production of metabolic by-products, such as propionate and butyrate, capable of damaging epithelial cells.

- In addition, the BV-associated anaerobes release volatile amines (especially putrescine, trimethylamine and cadaverine), responsible for the characteristic fishy malodour. Amines appear in the vaginal environment after conversion of amino acids produced by abundance of anaerobes, and form in combination with nitrites(produced by nitrate reducing bacteria) nitrosamines. These carcinogenic compounds are capable of forming DNA adducts and consequently mutagenic events. Previous investigations suggest that local accumulation of nitrosamines during episodes of $\mathrm{BV}$ may induce cell transformation of the cervical epithelium, in concert with other oncogenic agents like HPV infection.

- Alternatively, alterations in inflammatory cytokine profile present in a disturbed vaginal environment could promote development of cervical lesions. ${ }^{[8-11]}$

- A disturbed vaginal microflora might therefore indirect predispose to cervical dysplasia.

- However, other researchers have refuted this association of BV with cervical neoplasia. ${ }^{[12,13]}$

\section{Aims and Objectives}

To find out the association between Nugent score in gramstained smears and pre neoplastic lesions in the Pap smears of patients with vaginal discharge

\section{Subjects and Methods}

- Sterile gloves

- Sterile Speculum

- Ayres Spatula

- Cervical brush

- Microscopic glass slides

- Gram stain kit

- Fixative for Papanicolaou stain

- Rapid Pap staining kit

- Compound microscope

\section{Methodology}

- Study design-DescriptiveStudy participants (human)

- Inclusion criteria-Cervical Smears from women between 18-49 yrs of age with vaginal discharge.

- Exclusion criteria- Cervical Smears from Postmenopausal women, Pregnant women

- Sampling population - Cervical Smears from women of reproductive age group with white discharge

- Sample size -100

- Preparation of sample

$>$ Cervical smears were taken under aseptic precautions, wet fixed and stained with Papanicolaou stain. ${ }^{[14]}$

$>$ The same cervical samples will be used for preparing smear for Nugent score. After heat fixation, smears will be gram stained and examined under oil immersion at $100 \mathrm{X}$ magnification. ${ }^{[15]}$

$>$ Gram stained smears were coded and given Nugents score and classified in to normal vaginal flora, intermediate and Bacterial vaginosis. 
$>$ PAP smears were reported according to the Bethesda III system (2001): atypical squamous cell (ASC), lowgrade squamous intraepi-thelial lesion (LSIL), highgrade squamous intraepithelial lesion (HSIL). LSIL includes CIN 1 and koilocytotic atypia. ${ }^{[16]}$

$>$ PAP smears without dysplastic changes are categorized under the term NILM(Negative for intra epithelial lesion/malignancy)

$>$ The proportion of cervical smears with normal flora and dysplastic changes as well as that of smears with bacterial vaginosis and dysplastic changes were calculated and compared.

\section{Results}

\section{Prevalence of Bacterial Vaginosis}

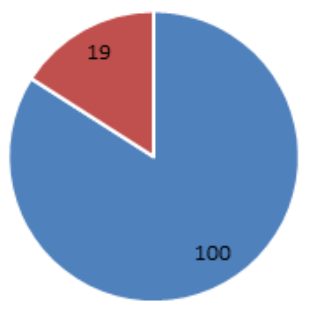

- total = Bacter ial vaginosis

Figure 1: Prevalance of Bacterial Vaginosis.

During the study period 100 cervical smears were PAP stained and the corresponding gram stained smears were scored for Bacterial vaginosis.

Of these, 38 smears were having normal vaginal flora, 43 smears were having intermediate (bacterial colonization) and 19 smears (19\%) were scored as having Bacterial Vaginosis. [Figure 1]

Table 1: Comparison of pre neoplastic lesions in PAP smear to Nugent score in Gram stained smears

\begin{tabular}{|l|l|l|l|}
\hline $\begin{array}{l}\text { PAP Smear report } \\
\text { (Bethesda 2001) }\end{array}$ & \multicolumn{2}{|l|}{ Nugent score } \\
\hline Total-n=100 & $\begin{array}{l}0-3 \\
\text { (Normal } \\
\text { flora) }\end{array}$ & $\begin{array}{l}4-7 \\
\text { (Intermediate) }\end{array}$ & $\begin{array}{l}8-10 \\
\text { (Bacterial } \\
\text { Vaginosis) }\end{array}$ \\
\hline $\begin{array}{l}\text { Epithelial cell } \\
\text { abnormalities(Dysplasia) } \\
\mathrm{n}=9\end{array}$ & 1 & 6 & 2 \\
\hline $\begin{array}{l}\text { NILM(Negative for intra } \\
\text { epithelial } \\
\text { lesion/malignancy)n=91 }\end{array}$ & 37 & 37 & 17 \\
\hline
\end{tabular}

Bacterial vaginosis smears were correlated with their PAP smear findings to find out if there is any association of dysplastic changes.Most of the smears were having reactive cellular changes mainly in the form of nucleomegaly .2 out of 19 smears (10.5\%)were showing epithelial cell abnormality reported as ASC [Table 1].

1 out of $38(2.6 \%)$ smears having normal vaginal flora was showing epithelial cell abnormality reported as ASC and 6 out of $43(14 \%)$ smears in the intermediate category showed epithelial cell abnormalities,5 ASC and 1- HSIL. [Table 2]

Statistical analysis was done by Chi-square test using IBMSPSS Statistics-22 statistical package. The correlation between Bacterial vaginosis and dysplastic changes were not found to be statistically insignificant as the $\mathrm{p}$ value were 0.07 and 0.208 while comparing normal versus intermediate category and normal versus bacterial vaginosis category respectively (greater than 0.05 ).

Table 2: Frequency of dysplastic changes in BV Compared to those with normal and intermediate flora.

\begin{tabular}{|l|l|l|}
\hline Nugent score & No of smears & $\begin{array}{l}\text { No of smears with } \\
\text { dysplastic changes } \\
(\%)\end{array}$ \\
\hline Normal flora & 38 & $1(2.6 \%)$ \\
\hline Intermediate & 43 & $6(14 \%)$ \\
\hline Bacterial vaginosis & 19 & $2(10.5 \%)$ \\
\hline
\end{tabular}

\section{Discussion}

Bacterial vaginosis (BV) is a syndrome of replacement of lactobacilli-dominated flora by a complete mix of strict and facultative anaerobic bacteria. The altered flora in BV is constituted mainly by gardenerella as also micrococci, streptococci and staphylococci (Frega et al., 1997). The prevalence of BV in different clinical settings has been reported to variably range from $10 \%$ to $64 \%$ (Kenyon et al., 2013). The prevalence of BV in the study of Bump et al is $13 \%$ and $28.6 \%$ in the study of Sodhani et al.. ${ }^{[2,17]}$

In this study out of 100 cervical smears 19 smears were scored as having Bacterial vaginosis (BV).This prevalence of Bacterial vaginosis (19\%) is almost similar to Peters et al $(20 \%){ }^{[12]}$

In this study it was found that dysplastic changes were more common in the intermediate category $(14 \%)$ rather than in Bacterial vaginosis (10.5\%) We hypothesize that the difference in the bacterial load between intermediate category and Bacterial vaginosis with consequent variation in the level of carcinogenic substance production might underlie the observed disparity in the association of the two types of smears with cervical preneoplasia. All of the BV patients had cytological abnormalities and discriminating between benign reactive changes and Atypical squamous cells is a subjective process

Platz-Christensen et al reported a significantly increased risk of CIN if BV was present. ${ }^{[7]}$ This finding has been supported by other authors as well (Nam et al., 2009; Roeters et al, 2010). ${ }^{[20,21]}$ More recent studies, including a meta-analysis by Gillet et al., (2011), ${ }^{[22]}$ have also reported a positive association between $\mathrm{BV}$ and presence of CIN .

We did not find a correlation of dysplastic changes and Bacterial vaginosis which was almost similar to the study of Peters et al (1995). ${ }^{[12]} \mathrm{He}$ did not find any association between BV and dyskaryosis or severity of CIN. Study by Jahic et al also showed no significant difference in the frequency of BV in LSIL and normal cervical smear (Jahic et al., 2013). ${ }^{[13]}$

Hence, this question of any plausible association between 
$\mathrm{BV}$ and cervical precancer and cancer is still unanswered with conflicting results.

\section{Conclusion}

There is no definite Correlation of Bacterial vaginosis with dysplastic changes in the PAP smear related with the risk for cervical carcinogenesis [Figure 2]. Cytological interpretation of infections may not always be fully accurate. Another limitation is that the number of samples in this study was small and observation spanned over a limited time period. Evaluation of larger cohort of subjects over a prolonged time frame is required to assess the influence of Bacterial vaginosis in cervical carcinogenesis.

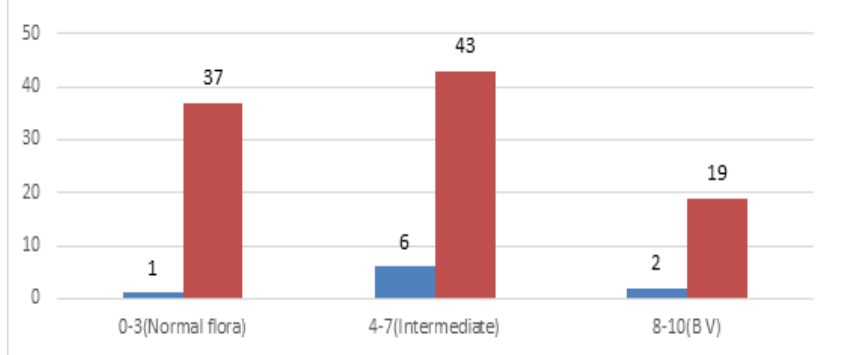

Association of dysplasia dyppreAP Smbear and Nugent score

Figure 2: Correlation of Bacerial vaginosis with dysplastic changes.

\section{Summary}

The study was conducted to find out the association between Nugent score in gram stained smears and pre neoplastic lesions in the Pap smears of 100 patients with vaginal discharge. Out of these, 38 smears were having normal vaginal flora, 43 smears were having intermediate (bacterial colonization) and 19 smears (19\%) were scored as having Bacterial Vaginosis. Only 2 out of the19 smears $(10.5 \%)$ were showing epithelial cell abnormality. On the contrary, 6 out of $43(14 \%)$ smears in the intermediate category showed epithelial cell abnormalities. Statistical analysis was done by Chi-square test using IBM-SPSS Statistics-22 statistical package. The correlation between Bacterial vaginosis and dysplastic changes were not found to be statistically significant as the $\mathrm{p}$ value were 0.07 and 0.208 while comparing normal versus intermediate category and normal versus bacterial vaginosis category respectively (greater than 0.05 ). In the very few studies conducted regarding this association, the results were contrasting and our study concludes to oppose this hypothesis

\section{Acknowledgement:}

Funding: Indian council of medical research (ICMR), New Delhi, India.

\section{References}

1. Westrom I, Evaldson G, Holmeskk, VanderMeijden W, Rijlande E, Fredrikson B. Taxonamy of Vaginosis: bacterial vaginosis-a definition. Scand J Urol Nephrol 1984:86(suppl);259-260.

2. Sodhani P, Gupta S, Gupta R, Mehrotra R. Bacterial Vaginosis and Cervical Intraepithelial Neoplasia: Is there an Association or is CoExistence Incidental?. Asian Pac J Cancer Prev 2001;18(5):1289-1292.

3. FIGO, IFoGaO. Global Guidance For Cervical CancerPrevention and Control 2009.

4. Huh WK. Human papillomavirus infection: a concise review of natural history. Obstet Gynecol 2009;114:139-143.

5. Spiegel CA, Amsel R, Holmes KK. Diagnosis of bacterial vaginosis by direct Gram stain of vaginal fluid. J Clin Microbiol 1983; 18 : 1707.

6. Nugent RP, Krohen MA, Hillier SL. Reliability of diagnosing bacterial vaginosis is improved by a standardized method of gram stain interpretation. J. Clin. Microbiol. 1991;29:297-301.

7. Platz-Christian sen JJ, Sundstrom E, Larsson P. Bacterial vaginosis and cervical intraepithelial neoplasia. Acta Obstetrica et Gynecologica Scand 2009;73:586-88.

8. Verbruggen BS, Boon ME, Boon LM. Dysbacteriosis and squamous (pre) neoplasia of immigrants and Dutch women as established in population-based cervical screening. Diagn Cytopathol, 2006; 34:37781.

9. Watts DH, Fazzari M, Minkoff H. Effects of bacterial vaginosis and other genital infections on the natural history of human papillomavirus infection in HIV-1-infected and high-risk HIV-1-uninfected women. J Infect Dis 2005;191:1129-1139.

10. Wolrath H, Forsum U, Larsson PG, Boren H. Analysis of bacterial vaginosis-related amines in vaginal fluid by gas chromatography and mass spectrometry. J Clin Microbiol 2001;39: 4026-4031.

11. Pavić N. Is there a local production of nitrosamines by the vaginal microflora in anaerobic vaginosis/trichomoniasis. Med Hypotheses 1984; 15:433-6.

12. Peters N, Van Leeuwen AM, Pieters WJ, (1995). Bacterial vaginosis is not important in the etiology of cervical neoplasia: a survey on women with dyskaryotic smears. Sex Transm Dis, 22, 296-302

13. Jahic M, Mulavdic M, Hadzimehmedovic A, Jahic E (2013). Association between aerobic vaginitis, bacterial vaginosis and squamous intraepithelial lesion of low grade. Med Arch, 67, 94-6

14. Koss LG. The Papanicolaou Test for Cervical Cancer DetectionA Triumph and a Tragedy. JAMA.1989;261(5):737-743

15. Thairu Y, Nasir IA, Usman Y. Laboratory perspective of gram staining and its significance in investigations of infectious diseases. SubSaharan Afr J Med 2014;1:168-74

16. The 2001 Bethesda System: terminology for reporting results of cervical cytology.Solomon D1, Davey D, Kurman R, Moriarty A, O'Connor D, Prey M, Raab S, Sherman M, Wilbur D, Wright T Jr, Young N; Forum Group Members; Bethesda 2001 Workshop. JAMA. 2002 Apr 24;287(16):2114-9.

17. Bump RC, Buesching WJ. Bacterial vaginosis in virginal and sexually active adolescent females: evidence against exclusive sexual transmission. Obstet Gynecol 1988;158:935-939.

18. Frega A, Stentella P, Spera G. Cervical intraepithelial neoplasia and bacterial vaginosis: correlation or risk factor? Eur J Gynaecol Oncol 1997;18:76-7.

19. Kenyon C, Colebunders R, Crucitti T. The global epidemiology of bacterial vaginosis: a systematic review. Am J Obs Gynecol 2013;209: 505-23.

20. Nam KH, Kim YT, Kim SR. Association between bacterial vaginosis and cervical intraepithelial neoplasia. J Gynecol Oncol 2009; 20:3943.

21. Roeters AM, Boon ME, van Haaften M. Inflammatory events as detected in cervical smears and squamous intraepithelial lesions. Diagn Cytopathol 2010;38:85-93.

22. Gillet E, Meys JF, Verstraelen H. Bacterial vaginosis is associated with uterine cervical human papillomavirus infection: a meta-analysis. BMC Infect Dis 2001;11:10-3. 
Copyright: () the author(s), 2020. It is an open-access article distributed under the terms of the Creative Commons Attribution License (CC BY 4.0), which permits authors to retain ownership of the copyright for their content, and allow anyone to download, reuse, reprint, modify, distribute and/or copy the content as long as the original authors and source are cited.

How to cite this article: Aruna P, Arora K. Correlation of Dysplastic Changes of Squamous Epithelial Cells to Bacterial Vaginosis Based on Nugent Score in the Cervical Smears of Patients with Vaginal Discharge. Asian J. Med. Res. 2020;9(1):PT01-PT05.

DOI: dx.doi.org/10.47009/ajmr.2020.9.1.PT1

Source of Support: Nil, Conflict of Interest: None declared. 